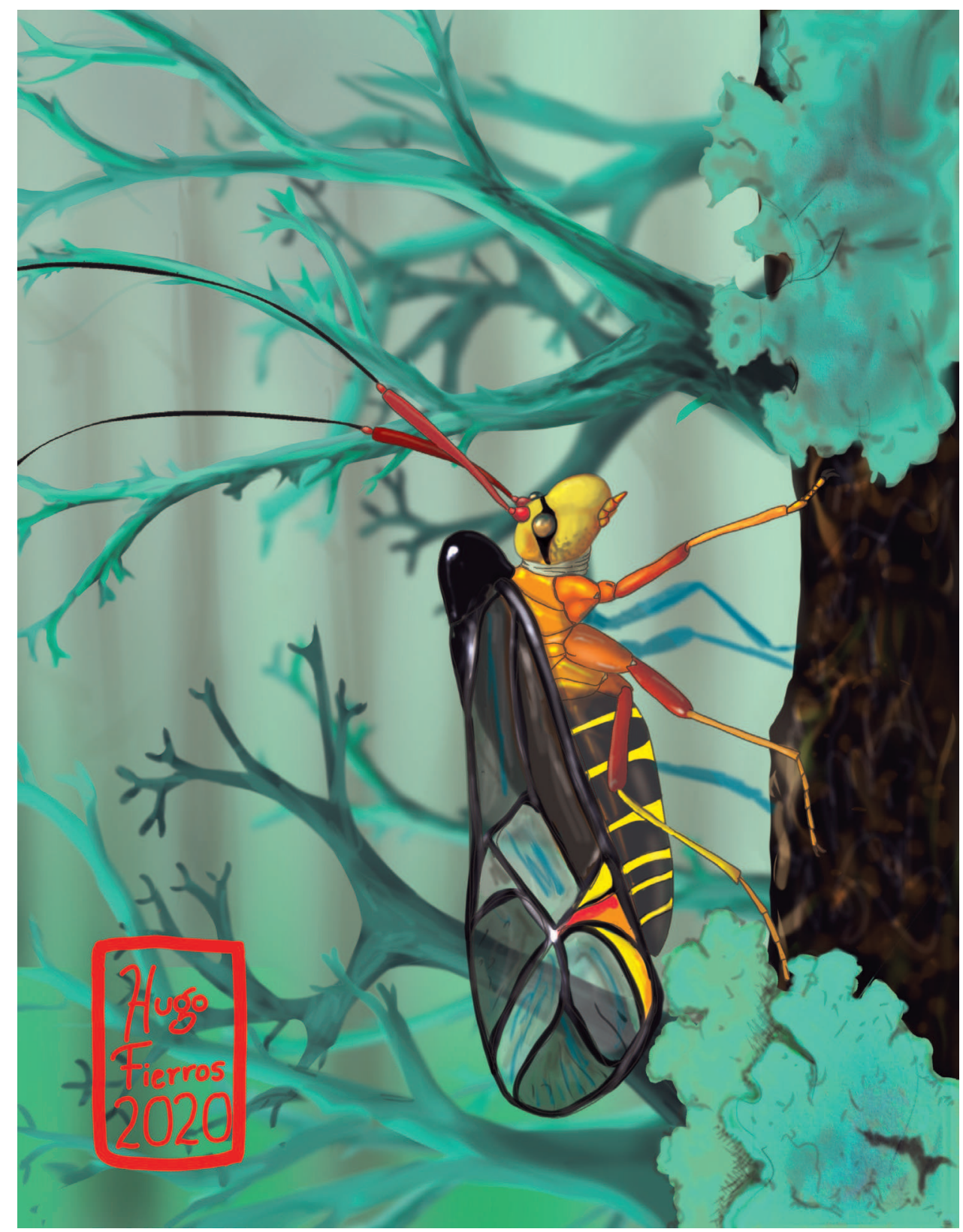

Dugesiana, Año 27, No. 2, julio 2020-diciembre 2020 segundo semestre de 2020), es una publicación semestral, editada por la Universidad de Guadalajara, a través del Centro de Estudios en Zoología, por el Centro Universitario de Ciencias Biológicas y Agropecuarias. Camino Ramón Padilla Sánchez \# 2100, Nextipac, Zapopan, Jalisco, Tel. 37771150 ext. 33218, http://148.202.248.171/dugesiana/index.php/DUG/index, glenusmx@gmail.com. Editor responsable: José Luis Navarrete-Heredia. Reserva de Derechos al Uso Exclusivo 04-2009-062310115100203, ISSN: 2007-9133, otorgados por el Instituto Nacional del Derecho de Autor. Responsable de la última actualización de este número: José Luis Navarrete-Heredia, Editor y Ana Laura González-Hernández, Asistente Editorial. Fecha de la última modificación 1 de julio 2020, con un tiraje de un ejemplar.

Las opiniones expresadas por los autores no necesariamente reflejan la postura del editor de la publicación.

Queda estrictamente prohibida la reproducción total o parcial de los contenidos e imágenes de la publicación sin previa autorización de la Universidad de Guadalajara. 


\title{
Two new species of Triplocania Roesler (Psocodea: 'Psocoptera': Ptiloneuridae), from Ecuador
}

\author{
Dos nuevas especies de Triplocania Roesler (Psocodea: 'Psocoptera': Ptiloneuridae), de Ecuador \\ Alberto Moreira da Silva Neto ${ }^{1^{*}}$, Marcelo Cutrim Moreira de Castroo ${ }^{1}$ José Albertino Rafael ${ }^{1}$ \\ ${ }^{1}$ Instituto Nacional de Pesquisas da Amazônia - INPA, CPEN - Programa de Pós-Graduação em Entomologia, \\ Campus II, Caixa postal 478, CEP 69011-97, Manaus, Amazonas, Brazil. E-mail: bio.alberto@gmail.com, marce- \\ locutrim@gmail.com, jarafael2@gmail.com \\ *Corresponding autor
}

\begin{abstract}
RESUMEN
Aquí se describien e ilustran dos especies nuevas de Triplocania Roesler, basadas en especímenes machos, para Ecuador, aumentando el número de especies ecuatorianas de Triplocania a siete. Se presenta la primera clave de identificación de especies de Triplocania de Ecuador. Las especies de Triplocania ecuatoriana aquí descritas aumentan la diversidad de Triplocania en Ecuador a siete especies, convirtiéndolo en el tercer país más diverso en Triplocania.

Palabras clave: Epipsocetae, psocidos, neotrópicos, taxonomía.
\end{abstract}

\begin{abstract}
Two new species of Triplocania Roesler, based on male specimens, were here described and illustrated for Ecuador, increasing the number of Ecuadorian species of Triplocania to seven. The first identification key to Triplocania species from Ecuador is presented. The Ecuadorian Triplocania species here described increase the diversity of Triplocania in Ecuador to seven species, making it the third most diverse country in Triplocania.
\end{abstract}

Key words: Epipsocetae, psocids, neotropics, taxonomy.

Triplocania Roesler (1940) is one of 10 genera in the psocopteran family Ptiloneuridae; it is the most speciose genus of the family, presently including 92 described species, with 37 species known only from males, 22 species known only from females and 33 species known from both sexes (Silva-Neto et al., 2018). The species occur in Belize, Bolivia, Brazil, Colombia, Ecuador, Guatemala, México, Nicaragua, Peru and Venezuela. Presently, Colombia and Brazil are the countries with the highest species richness of Triplocania; of the total number of species, 47 and 23 correspond to Colombia and Brazil respectively (Gonzalez-Obando et al., 2017). Previous to this work, only five species were known in Ecuador, Triplocania bravoi Silva-Neto, Rafale \& García Aldrete, 2015, Triplocania erwini Silva-Neto, Rafael \& García Aldrete, 2015, Triplocania ecuatoriana Silva-Neto, García Aldrete \& Rafael, 2016, Triplocania ecuatorianoides Silva-Neto, García Aldrete \& Rafael, 2016 and Triplocania triangularis Silva-Neto, García Aldrete \& Rafael, 2016. The purpose of this work is to describe and illustrate, based on male specimens, two new species of Triplocania from Ecuador. The first identification key to Ecuadorian Triplocania species is presented.

\section{MATERIAL AND METHODS}

Two male specimens were available for study. They were dissected in $80 \%$ ethanol, and their parts were mounted on slides in Canada balsam. Standard measurements (in $\mu \mathrm{m})$ were taken with a filar micrometer. Abbreviations of parts measured are as follows: FW and HW: right fore- and hind- wing lengths; $\mathrm{F}, \mathrm{T}, \mathrm{t} 1, \mathrm{t} 2$ and $\mathrm{t} 3$ : lengths of femur, tibia and tarsomeres 1, 2 and 3 of right hind leg; fl...fn: lengths of flagellomeres $1 \ldots \mathrm{n}$ of right antenna; Mx4: length of fourth segment of right maxillary palpus; IO: minimum distance between compound eyes in dorsal view of head; $\mathrm{D}$ and $\mathrm{d}$ : antero-posterior and transverse diameter, respectively, of right compound eye in dorsal view of head; PO: $\mathrm{d} / \mathrm{D}$. The final storage of the specimens was in CD boxes, as described by Silva-Neto et al. (2016).

Photographs of the parts mounted were taken with a Leica DFC500 digital camera attached to a Leica M205C stereomicroscope, connected to a computer with the Leica Application Suite LAS V3.6 software, which includes an Auto-Montage module (Syncroscopy software).

The types will be deposited in the Invertebrate Collection of the The Zoology Museum at the Pontifical Catholic University of Ecuador in Quito, Ecuador (QCAZ). 


\section{RESULTS}

Key to the Ecuadorian Triplocania species

1. Setae of the forewing veins not arising from brown areolae (Figs. 16, 17)

1 '. Setae of the forewing veins arising from brown areolae (Figs. 2, 9, 18, 19, 20)

2. Forewings with a homogeneous brown marginal band brown from $\mathrm{R} 4+5$ to almost $\mathrm{CuA} 2$, with proximal third dark brown (Fig. 16); hypandrium with side sclerites fused to the central piece, and it with two forked posterior projections, horn shaped (Fig. 21)

Triplocania bravoi Silva-Neto, Rafael \& García Aldrete.

2'. Forewing with a submarginal brown band with convex hyaline fenestrae on outer border between each intersection of the veins and the edge of the wing from R2+3 to areola postica, areola postica with a dark brown spot between its apex and M vein (Fig. 17); hypandrium with side sclerites not fused to the central piece, and two short, blunt ended, median in the central sclerite (Fig. 22)

Triplocania erwini Silva-Neto, Rafael \& García Aldrete.

3. Forewing with a submarginal brown band with convex hyaline fenestrae on outer border between each intersection of the veins and the edge from $\mathrm{R} 2+3$ to areola postica (Figs. 9, 20); central sclerite of hypandrium with a not bilobed median projection (Figs. 12, 23); mesal transverse endophallic sclerite present

... 4

3 '. Forewing with a submarginal brown band with hyaline concavities on inner border between each intersection of the veins and the edge (Figs. 18, 19) or marginal pigmentation of forewing present only on veins distally (Fig. $2)$; central sclerite of hypandrium with a bilobed median projection, with a cleft in the middle (Figs. 5, 25); mesal transverse endophallic sclerite absent ...........5

4. Central sclerite of hypandrium with a triangular posterior process (Fig. 23); mesal transverse endophallic sclerite anteriorly concave, posteriorly with two small acuminate process (Fig. 24)

Triplocaniatriangularis Silva-Neto, GarcíaAldrete\&Rafael.

4' Central sclerite of hypandrium with a spearhead shaped posterior process (Fig. 12); mesal transverse endophallic sclerite anteriorly convex, with two small triangular projections on each side, posteriorly slightly concave in the middle (Fig. 13) ...................... Triplocania pumas n. $\mathbf{s p .}$

5. Posterior median process of the central sclerite of the hypandrium with short apical lobes (Fig. 5); phallosome with seven pairs of endophallic sclerites (Fig. 6) Triplocania alfonsoi $\mathbf{n} . \mathbf{s p}$.

5 '. Posterior median process of the central sclerite of the hypandrium with elongated apical lobes (Fig. 25); phallosome with three pairs of endophallic sclerites (Figs. 26, 27)

6. Anterior pair $\mathrm{Y}$ shaped of the endophallic sclerites with basal part ending in three acuminate exten- sions, two short near the end, and one long, slender, curved inward, inner and outer arms blunt ended (Fig. 26)

Triplocania ecuatorianoides Silva-Neto, García Aldrete \&Rafael.

6'. Anterior pair $\mathrm{Y}$ shaped of the endophallic sclerites with basal part ending in only a acuminate extension, long, incurved inward, inner and outer arms distally acuminate (Fig. 27)

Triplocania ecuatoriana Silva-Neto, García Aldrete \&Rafael.

\section{Descriptions \\ Triplocania alfonsoi $\mathbf{n}$. sp. Male \\ (Figs 1-7) \\ http://zoobank.org/7B14F7EF-BFD1-47F4-9E3D-CF- D9EC5B9E94}

Diagnosis. Forewing with setae of veins arising from dark brown areolae; elliptical brown spots on veins distally, from $\mathrm{R} 2+3$ to $\mathrm{CuA} 2$; central sclerite of hypandrium distally cleft in the middle, with projections directed outwards; phallosome with seven pairs of endophallic sclerites.

Color. (parts mounted on slide). Thorax and Abdomen missing. Compound eyes black, ocelli hyaline, with ochre centripetal crescents, head pattern (Fig. 1). Antennae with scape and pedicel yellow, f1-f3 pale yellow. Mx4 pale yellow with apex yellow. Legs with coxae, trochanters and femora pale yellow, tibiae yellow, with apex pale brown; tarsomeres 1-3 yellow. Forewing with setae of veins arising from dark brown areolae, elliptical brown spots on veins distally, from $\mathrm{R} 2+3$ to $\mathrm{CuA} 2$; a brown spot between Rs and branching of $\mathrm{M}$ and between apex of areola postica and $\mathrm{M}$; a brown area along $\mathrm{CuA}$ to posterior end of $\mathrm{CuP}$; a brown spot at confluence of $\mathrm{CuP}-1 \mathrm{~A}$; a brown irregular area on proximal end of wing; pterostigma brown, with a large, hyaline area in the middle; veins brown, with dark brown spots at wing margin (Fig. 2). Hindwing almost hyaline, with a small, pale brown area proximally and a small pale brown spot at confluence of $\mathrm{CuP}$ and wing margin; veins brown, with dark brown spots at wing margin (Fig. 3).

Morphology. Head with vertex concave in the middle, slightly above the level of the upper border of the compound eyes, these without interommatidial setae (Fig. 1). Outer cusp of lacinial tip broad, with four denticles (Fig. 4). Forewing pterostigma almost triangular, narrow basally; Rs concave in the middle, R2+3 and R4 +5 almost straight, M1 slightly convex, M2 almost straight, M3 straight; areola postica tall, almost touching the $\mathrm{M}$ vein, with rounded apex, 2A not reaching the wing margin (Fig. 2). Hindwing Rs, after Rs $+\mathrm{M}$, almost straight, R2+3 straight, R4+5 almost straight, M sinuous. Hypandrium of three sclerites, a large central sclerite, anteriorly convex, with mesal processes directed outwards; posterior process stout; distally cleft in the middle, with two short lobes projections directed outwards; setae as illustrated (Fig. 5). Phallosome (Fig. 6) with side struts independent, Y shaped, fused posterior- 
ly to slender external parameres, curved inwards, almost elliptical, bearing a field of pores distally; seven pairs of endophallic sclerites; anterior pair elongate, curved inwards, basally pointed, distally acuminate; antero-lateral pair, small, narrow anteriorly, posteriorly wide and almost rectangular; mesal pair, elongated, almost together in the middle, anterioly almost straight with a small triangular projection on the side, posteriorly projected outwards; a lateral pair elongated, anterioly with two forked projections, distally curved inward and acuminated; a postero-lateral pair, stout, elongetd, narrow anteriorly, wide posteriorly with end tip broad; a postero-mesal pair elongetd, anteriorly almost traiangular, with acuminated apex, posteriorly almost rectangular with square ápex; a posterior pair, short, with three small acuminate projections on the outer margin. Epiproct wide basally, triangular, three setae on mesal field, distal setae as illustrated (Fig. 7). Paraprocts broadly semi-elliptic, sensory fields with 28-29 trichobothria on basal rosettes, setae as illustrated (Fig. 7).

Measurements (in microns). FW: 3145, HW: 2188, F: 855, T: 1351, t1: 584, t2: 78, t3: 109, f1: 487, f2: 335, f3: 310, Mx4: 239, IO: 417, D: 288, d: 187, PO: 0.65.

Material examined. Holotype male (QCAZ). Ecuador. Napo. Reserva Étnica Waorani, $1 \mathrm{Km}$ S. Onkone Gare Camp. 220m. 10.II.1995. 0³0'10”S: 76²6’ 0”W. Fogging terre firma forest. T. L. Erwin et al.

Etymology. This species is dedicated to Dr. Alfonso Neri Garcia Aldrete, of the Universidad Nacional Autónoma de México, Mexico, in recognition to his important contributions in the taxonomy of Neotropical Psocoptera.

\section{Triplocania pumas $\mathbf{n}$. sp. Male}

(Figs 8-15)

http://zoobank.org/EE4B0275-9E67-40C3-92D46EA56241A585

Diagnosis. Setae on forewing veins arising from dark brown areolae, with a brown band with a convex hyaline fenestrae on outer border between each intersection of the veins and the edge of the wing from the distal end of the pterostigma to $\mathrm{CuA} 2$; hypandrium of three sclerites, with a large central sclerite with a spearhead shaped posterior process in the middle; mesal endophallic sclerite anteriorly convex, with two small triangular projections on each side, posteriorly slightly concave in the middle; five pairs of endophallic sclerites.

Color. (parts mounted on slide). Thorax and Abdomen missing. Compound eyes black, ocelli hyaline, with ochre centripetal crescents; head pattern (Fig. 8). Antennae with scape pale brown, pedicel pale yellow; f1-f3 pale yellow. Mx4 brown. legs with femora pale yellow; tibiae pale brown with distal ends brown; tarsomere 1 pale yellow, tarsomeres 2-3 pale brown. Forewing with setae of veins arising from dark brown areolae, with a brown band from the distal end of the pterostigma to $\mathrm{CuA} 2$ with a convex hyaline fenestrae on outer border between each intersection of the veins and the edge of the wing; a brown area almost triangular along $\mathrm{CuA}$ to end of $\mathrm{CuP}$; a small dark brown spot at confluence of CuP-1A; a brown band along the areola postica; pterostigma almost pigmented throughout, with a clear area in the middle; veins brown, with brown areolae at setal insertions and with dark brown spots at wing margin (Fig. 9). Hindwing mostly hyaline, with a small pale brown area next to $\mathrm{CuP}$; veins brown, with brown spots at wing margin (Fig. 10).

Morphology. Head with vertex concave in the middle, slightly above the level of the upper border of the compound eyes, these without interommatidial setae (Fig. 8). Outer cusp of lacinial tip broad, with three denticles (Fig. 11). Forewing pterostigma almost triangular, Rs convex, $\mathrm{R} 2+3$ and $\mathrm{R} 4+5$ sinuous, $\mathrm{M}$ stem concave proximally, then almost straight, M1, M2 and M3 sinuous, areola postica tall, wide basally, slightly slanted posteriorly, with round apex, 2A not reaching the wing margin (Fig. 9). Hindwing Rs straight, R2+3 and R4+5 straight, M sinuous. Hypandrium of three sclerites, a large central sclerite convex anteriorly, with a spearhead shape posterior process in the middle, flanked by two smaller, setose, almost triangular sclerites (Fig. 12). Phallosome (Fig. 13) with side struts independent, $\mathrm{V}$ shaped, fused posteriorly to external parameres, these with tip broad and with a field of pores posteriorly. Mesal endophallic sclerite fused, wide, strongly sclerotized, anteriorly convex, with two small triangular projections on each side, posteriorly slightly concave in the middle; additionally five pairs of endophallic sclerites; anterior pair, elongated, slender, anteriorly curved with a tip rounded apex, posteriorly heavily sclerotized, initially straight, then abruptly curving distally and together in the middle of endophallus; a pair transverse, elongate, inner ends rounded, almost together in the middle, distally acuminate; lateral pair, small, next to outer margin of the external parameres, distally acuminate; mesal-posterior pair, small, elliptical, with field of small spicules; posterior pair V shaped, with inner arms narrower than outer arms, heavily sclerotized, distally acuminate, outer arms stout, wide, narrowing abruptly distally like a tail. Epiproct wide basally, semi-oval, three setae on mesal field position, other setae as illustrated (Fig. 14). Paraprocts broad, narrowing posteriorly, rounded, sensory fields with 27-28 trichobothria on basal rosettes, setae as illustrated (Fig. 15).

Measurements (in microns). FW: 3429, HW: 2391, F: 923, T: 1444, t1: 584, t2: 80, t3: 131, f1: 474, f2: 408, f3: 346, Mx4: 226, IO: 437, D: 324, d: 203, PO: 0.63.

Material examined. Holotype male (QCAZ). Ecuador. Napo. Reserva Étnica Waorani, 1Km S. Onkone Gare Camp. 220m. 11.II.1995. 0³0'10”S: 76026’ 0”W. Fogging terre firma forest. T. L. Erwin et al.

Etymology. The name is given to this species as a noun in apposition, and refers to Club de Fútbol Universidad Nacional A.C., commonly known as Pumas de la UNAM. This football team has Alfonso Neri Garcia Aldrete as a big fan. 


\section{DISCUSSION}

Ecuadorian Triplocania species here described increase the diversity of Triplocania in Ecuador to seven species, making it the third most diverse country in Triplocania, second only to Brazil (23 species) and Colombia (47 species). The fourth and fifth most diverse country in Triplocania are México (six species) and Peru (five species).

Setae of the forewing veins arising from brown areolae is a character state present in $T$. alfonsoi $\mathbf{n}$. sp. and T. pumas n. sp., and it is shared by T. triangularis, T. fapeam Silva-Neto, García Aldrete \& Rafael, 2016, T. inpa Silva-Neto, García Aldrete \& Rafael, 2016, T. manauara Silva-Neto, García Aldrete \& Rafael, 2016, T. bifida García Aldrete, 1999, T. umbrata New, 1980, T. ecuatoriana, T. ecuatorianaoides, T. amacayacuensis Gonzalez-Obando, Carrejo-Gironza \& García-Aldrete, 2017, T. asisensis Gonzalez-Obando, Carrejo-Gironza \& García-Aldrete, 2017 and T. umbrataoides Silva-Neto, García Aldrete \& Rafael, 2018, but the hypandrium and phallosome of two Ecuadorian Triplocania species here described are quite distinct (see diagnosis above).

The combination of the following characteristics: setae of the forewing veins arising from brown areolae and central sclerite of hypandrium with a bilobed median projection, present in T. alfonsoi n. sp., is shared in Triplocania by others six species, among these species T. ecuatoriana, T. ecuatorianaoides, T. umbrataoides and T. asisensis form a subgroup by having the posterior median process of the central sclerite of the hypandrium with elongated apical lobes, originating a deeply cleft and by having phallosome with only three pairs of endophallic sclerites. T. alfonsoi $\mathbf{n}$. sp., T. amacayacuensis and T. manauara constitute an other subgroup by having the posterior median process of the central sclerite of the hypandrium with short apical lobes, not originating a deeply cleft distally. T. alfonsoi $\mathbf{n}$. sp. differs from them in having seven distinct pairs of endophallic sclerites, just because T. manauara has only two pairs of endophallic sclerites and T. amacayacuensis has four pairs of endophallic sclerites.

Recibido: 28 marzo 2020

Aceptado: 14 junio 2020

\section{ACKNOWLEDGMENTS}

We thank Alfonso Neri García Aldrete for all the knowledge provided for the academic formation of the authors A.M.S.N. and M.C.M.C. in the fantastic Psocoptera world. We also thanks Instituto Nacional de Pesquisas da Amazônia (INPA), Conselho Nacional de Desenvolvimento Científico e Tecnológico of Brazil (CNPq) and Coordenação de Aperfeiçoamento de Pessoal de Nível Superior (CAPES) for research support. AMSN thanks particularly the support for the Capes-INPA research grant (Process: 88887.312051/2018-00). JAR thanks particularly the support for the Cnpq research grant (Process: 300.997/20167). Of the total of 96 known Triplocania species, Alfonso Neri Garcia Aldrete is author or co-author of 84 species of this genus, this fact demonstrates the enormous importance of this Psocoptera specialist in increasing knowledge about the diversity of this Ptiloneuridae genus.

\section{LITERATURE CITED}

García Aldrete A.N. 1999. New species of Triplocania Roesler from Mexico, Central and South America (Insecta, Psocoptera, Ptiloneuridae). Spixiana, 22(2): 149-166.

New T.R. 1980. Epipsocetae (Psocoptera) from the Reserva Ducke, Amazonas. Acta Amazonica, 10(1): 179-206.

Gonzalez-Obando, R.; Carrejo-Gironza, N.S. \& García Aldrete, A.N. 2017. New species of Colombian Triplocania Roesler (Psocodea: 'Psocoptera': Ptiloneuridae). Zootaxa, 4336(1): 001-113. https://doi.org/10.11646/ zootaxa.4336.1.1

Silva-Neto A.M., Rafael J.A. \& García Aldrete A.N. 2015. New species of Triplocania Roesler (Psocodea, 'Psocoptera', Ptiloneuridae), from Brazil and Ecuador. Zookeys, 505: 103-116. http://dx.doi.org/10.3897/zookeys.505.9870

Silva-Neto A.M., García Aldrete A.N. \& Rafael J.A. 2016. Twelve new species of Triplocania Roesler (Psocodea: 'Psocoptera': Ptiloneuridae), from South America. Zootaxa, 4109 (3): 251-283. http://doi.org/10.11646/zootaxa.4109.3.1

Silva-Neto, A. M., García Aldrete, A. N., \& Rafael, J. A. 2018. Triplocania Roesler: a new species, redescriptions, description of the female of Triplocania spinosa Mockford, and revalidation of the original combination of Belicania cervantesi (García Aldrete) (Psocodea: 'Psocoptera': Ptiloneuridae). Papéis Avulsos de Zoologia (Online), 58:1-11. 

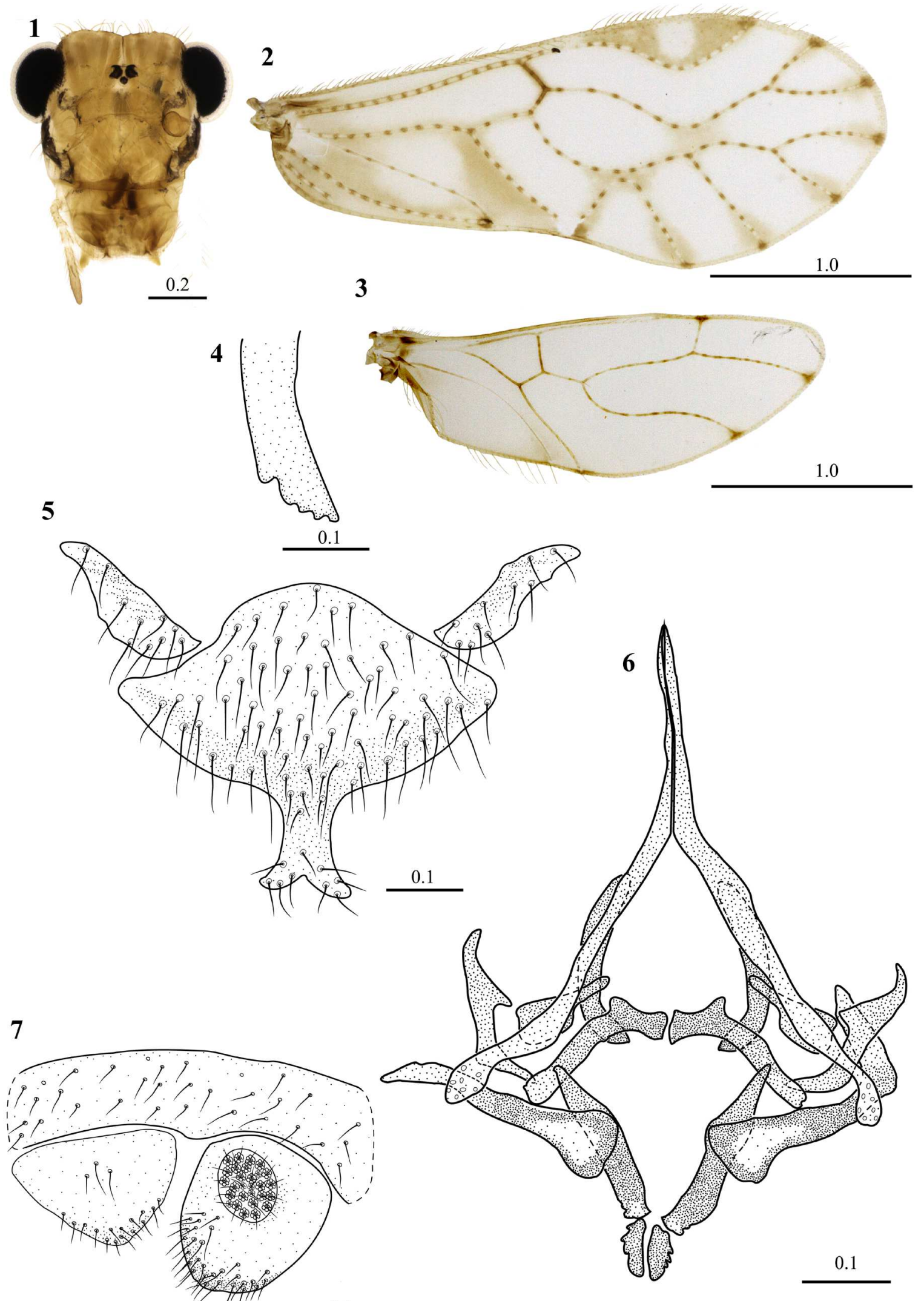

Figures 1-7. Triplocania alfonsoi n. sp. (Holotype male). 1. Front view of head. 2. forewing. 3. Hindwing. 4. Lacinial tip. 5. Hypandrium. 6. Phallosome. 7. Clunium, right paraproct and epiproct. Scales in $\mathrm{mm}$. 

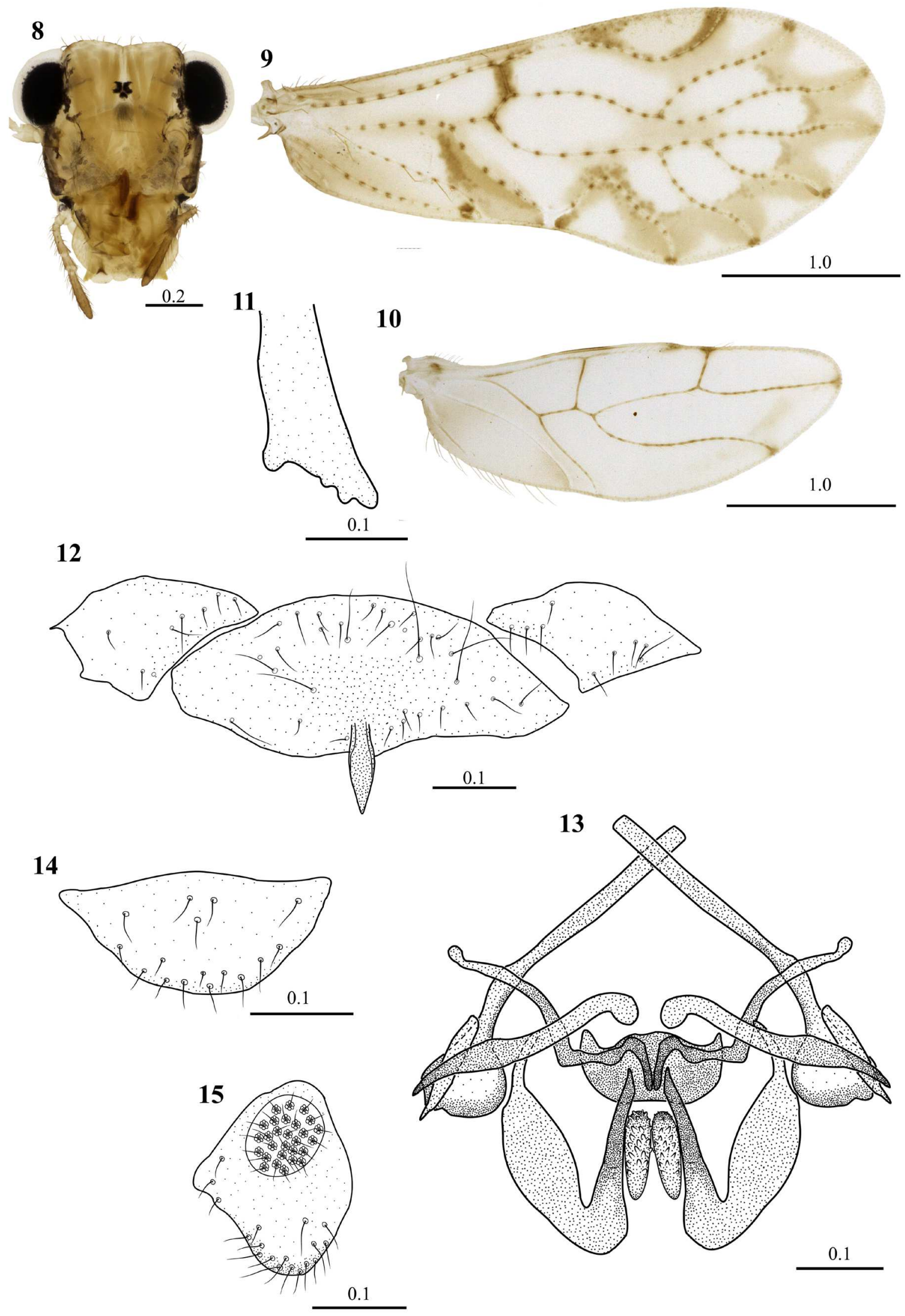

Figures 8-15. Triplocania pumas n. sp. (Holotype male). 8. Front view of head. 9. forewing. 10. Hindwing. 11. Lacinial tip. 12. Hypandrium. 13. Phallosome. 14. Epiproct. 15. Left paraproct. Scales in mm. 

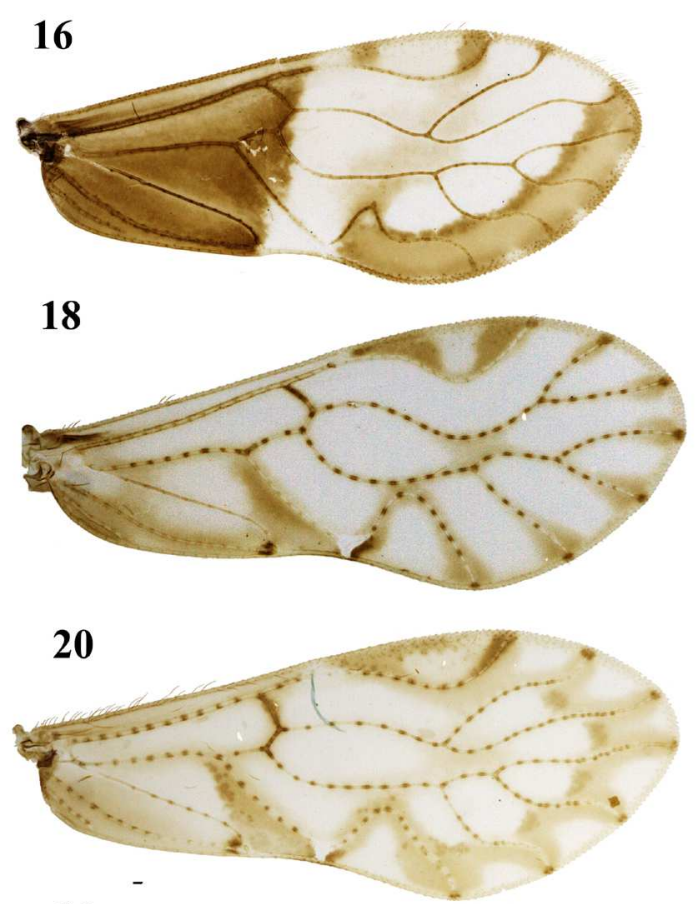

22

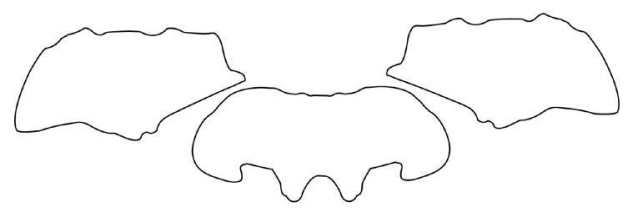

24
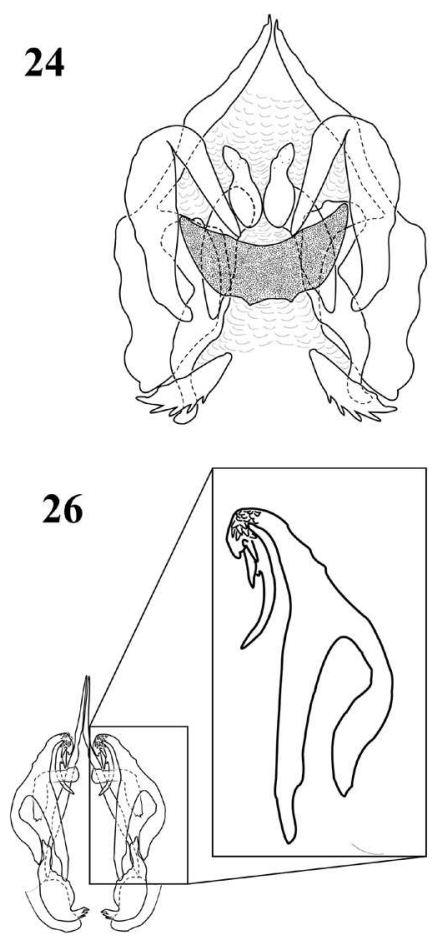

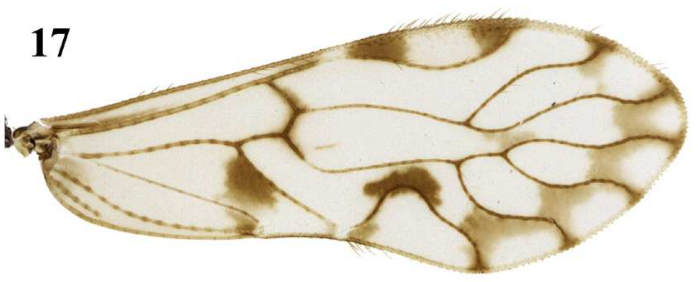

19

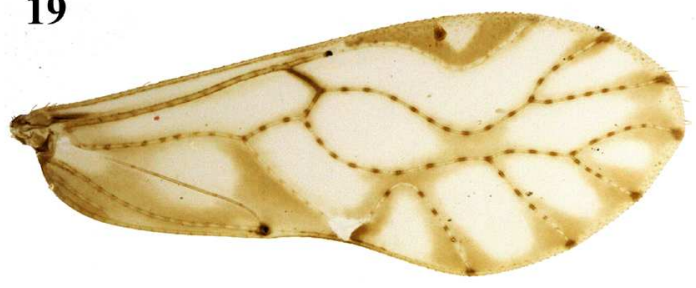

21

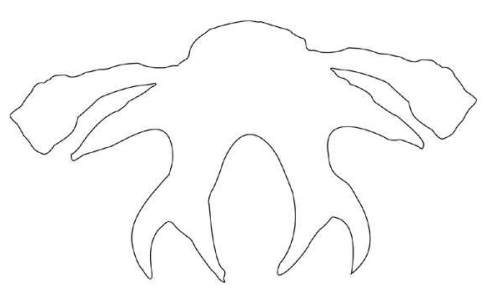

23

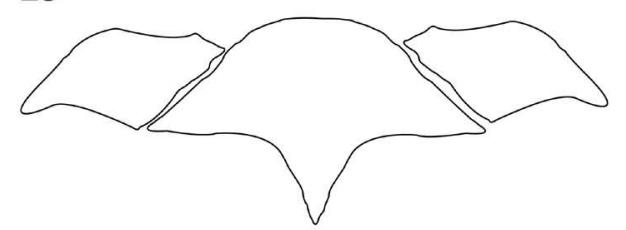

25
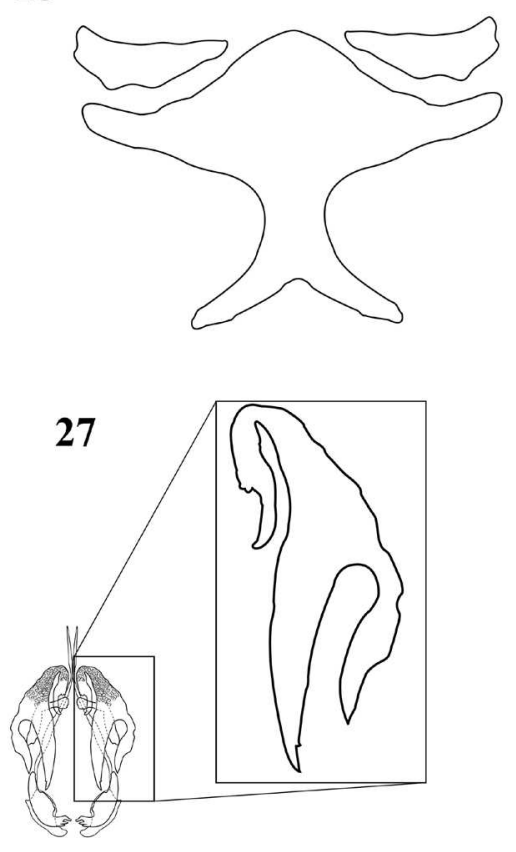

Figures 16-27. Forewing. 16. Triplocania bravoi. 17. Triplocania erwini. 18. Triplocania ecuatorianoides. 19. Triplocania ecuatoriana. 20. Triplocania triangularis. Hypandrium. 21. T. bravoi. 22. T. erwini. 23. T. triangularis. Phallosome with mesal transverse endophallic sclerite. 24. T. triangularis. Hypandrium. 25. T. ecuatorianoides. Phallosome with zoom of the left anterior endophallic sclerite. 26. T. ecuatorianoides. 27. T. ecuatoriana. All illustrations were based on holotype specimens. 